Instructions for authors, subscriptions and further details:

http://ijelm.hipatiapress.com

\title{
Instructional leadership: The role of heads of schools in managing the instructional programme
}

Aaron Mkanga Manaseh ${ }^{1}$

1) Mkawawa University College of Education. United Republic of Tanzania

Date of publication: January $16^{\text {th }}, 2016$

Edition period: January 2016-July 2016

To cite this article: Manaseh, A.M. (2016). Instructional leadership: The role of heads of schools in managing the instructional programme. International Journal of Educational Leadership and Management, 4(1), 3047. doi: 10.17583/ijelm.2016.1691

To link this article: http://dx.doi.org/10.17583/ijelm.2016.1691

\section{PLEASE SCROLL DOWN FOR ARTICLE}

The terms and conditions of use are related to the Open Journal System and to Creative Commons Attribution License (CC-BY). 


\title{
Instructional Leadership: The Role of Heads of Schools in Managing the Instructional Programme
}

\author{
Aaron Mkanga Manaseh \\ Mkawawa University College of Education
}

\begin{abstract}
Scholars and practitioners agree that instructional leadership (IL) can be one of the most useful tools for creating an effective teaching and learning environment. This paper investigates the instructional leadership practices engaged in by heads of secondary schools to enhance classroom instruction and students learning, particularly the way they manage the school instructional programme. Two objectives guided the study: to explore the informants' understanding on the concept of IL; and to examine the role played by heads of schools (HoSs) in managing the instructional programme to enhance teachers' classroom instruction and students' learning. It draws on the qualitative data generated from interviews, focus group discussions, and observations. The informants for this study were HoSs, senior academic masters/mistresses (SAMs), teachers and students. The study findings confirm that HoSs, SAMs, teachers and students were not familiar with the concept of IL. On the other hand, the instructional programme was not effectively managed as heads of departments were not involved in curriculum coordination, syllabi were not covered on time, and HoSs did not undertake classroom observations or engage in review of curriculum materials. The paper, however, concludes that without an effective management of the instructional programme in favour of promoting teachers' classroom instruction and students' learning, efforts to that effect are doomed to fail.
\end{abstract}

Keywords: instructional leadership, instructional programme, qualitative data inquiry, Tanzania 


\section{Liderazgo Instructivo: El Papel de los Directores de Escuela en la Gestión del Programa de Instrucción}

Aaron Mkanga Manaseh

Mkawawa University College of Education

\section{Resumen}

Académicos y profesionales están de acuerdo en que el Liderazgo Instructivo (IL) puede ser una de las herramientas más útiles para una enseñanza eficaz y un ambiente de aprendizaje. Este trabajo investiga las prácticas de IL aplicadas por directores de escuelas de secundaria para mejorar la enseñanza en clase y el aprendizaje de los estudiantes, en concreto, la forma cómo se gestiona el programa de instrucción escolar. Dos objetivos guiaron el estudio: explorar la comprensión de los informantes del concepto de IL; y examinar el papel de los directores de las escuelas en la gestión del programa de instrucción para mejorar la enseñanza de los profesores en el aula y el aprendizaje de los estudiantes. Se basa en datos cualitativos a través de entrevistas, grupos de discusión y observaciones. Los informantes fueron directores de escuela, profesores veteranos, profesores y estudiantes. Los resultados del estudio confirman que ninguno de ellos estaba familiarizado con el concepto de IL. Por otro lado, el programa de instrucción no estaba gestionado eficazmente ya que los jefes de departamento no estaban involucrados en la coordinación curricular, los programas de estudio no se cubrían a tiempo y los directores no llevaban a cabo observaciones en el aula o revisiones de los materiales curriculares. El estudio concluye que sin una gestión eficaz del programa de instrucción para promover la enseñanza en el aula y el aprendizaje de los estudiantes, los esfuerzos están condenados al fracaso. 
Palabras clave: liderazgo instructivo, programa de instrucción, investigación cualitativa, Tanzania

lobally, scholars agree that instructional leadership (IL) is one of the
most useful tools for creating an effective teaching and learning
environment (Pustejovsky, Spillane, Heaton \& Lewis, 2009; Hallinger \& Walker, 2014). In Tanzania, for example, the Ministry of Education and Vocational Training (MoEVT) (2011) through the secondary education development programme II document, stipulated that, among other duties, heads of secondary schools would be responsible for supervising the teaching programme, ensuring high quality teaching and learning, effective use of time for the entire school day and a conducive teaching and learning environment.

Instructional leadership is an educational leadership that focuses on the core responsibility of a school, namely teaching and learning, by defining the school vision, mission and goals, managing the instructional programme and promoting the school climate (Hoy \& Miskel, 2008). King (2002) asserted that the role of an instructional leader differs from that of a traditional school administrator in a number of meaningful ways: whereas the conventional head of school spends majority of his/her time dealing strictly with administrative duties, the head of school who is an instructional leader is charged with redefining his/her role to become the primary learner in a community striving for excellence in education. As such, it becomes the head of school's responsibility to work with teachers to manage the instructional programme. Instructional leaders know what is happening in the classrooms and develop the capacities of their staff by building on their strengths and reducing their weaknesses (Spillane \& Zuberi, 2009).

Instructional leaders go beyond the traditional role of school administrators and spend a lot more time focusing on developing knowledge and implementation of the curriculum, as well as instruction and assessment (Jita, 2010). The paper argues that improvement in learning is more likely to be achieved when the leadership is instructionally focused and located closest to the classroom. Despite the fact that IL is significant in promoting teachers' instructional practices and students learning, literature has shown that HoSs in Africa and Tanzania in particular, rarely engage in IL (Lwaitama \& Galabawa, 2008; World Bank, 2010). IL as described as overseeing 'teaching and learning' and 'supervising teachers' is not a 
function that takes up the majority of many HoSs' time. Furthermore, the recent researches on school leadership in Tanzania indicate that little has been devoted in studies relating to IL, particularly the engagement of HoSs in IL.

\section{Purpose of the Study}

This study aimed at establishing the current IL practices of heads of secondary schools in managing the instructional programme.

\section{Specific Objectives}

The specific objectives of this study were:

i. To explore the informants' understanding on the concept of instructional leadership.

ii. To examine the role played by heads of schools in managing the instructional programme to enhance teachers' classroom instruction and students' learning.

\section{Research Questions}

The following questions guided the inquiry:

i. How do informants understand the concept of instructional leadership?

ii. What role do heads of school play in managing the instructional programme to enhance teachers' classroom instruction and students' learning?

\section{Literature Review}

The literature surveyed indicated that IL is a significant factor in facilitating, improving and promoting teachers' classroom instructional practices and the academic progress of students (Spillane, Camburn \& Pareja, 2007; Pustejovsky, Spillane, Heaton \& Lewis, 2009; Spillane \& Zuberi, 2009). International empirical studies also affirm that IL plays a central role in shifting the emphasis of school-level activities more onto instructional improvements that lead to students learning better (Elmore, 2000; Spillane, 
Halverson \& Diamond, 2000; Day, Harris, Hadfield, Tolley \& Beresford, 2000; King, 2002). For example, McEwan (2009) through a synthesis of effective schools research in the United States of America developed ten traits of effective schools. The first ranked trait was that in academically successful schools strong instructional leadership was displayed.

However, in Australia Gillet (2010) interviewed heads of twenty secondary schools and found that their work had intensified over the period and had increasingly focused on financial administration to the exclusion of instructional leadership. Their work was more directed towards managerial issues rather than responding to instructional activities, all of which distanced HoSs from their staff and learners. In the same vein, in Canada Hallinger (2005) found that most HoSs often find themselves without the time, expertize or inclination to engage in hands-on supervision of classroom instruction. Even in smaller elementary schools, where head teachers are more likely to engage in this aspect of IL, the separation between head teacher and classroom remains strong.

In developing countries such as Uganda, Galabawa and Nikundiwe (2000) found that IL instilled the spirit of hard working in students and dedication on the part of teachers. It also enabled the maximum cooperation between parents and administrators, which eventually paved the way for better discipline, effective management and counselling. The result was decorum and a good atmosphere for learning, the best students were selected at the national level, and there were sufficient teachers as well as access to facilities such as laboratories and libraries. Furthermore, Hoadley, Christie, Jacklin and Ward (2007) in their study on 'Managing to learn: Instructional leadership in South African secondary schools found that HoSs reported spending most of their time on administrative functions and disciplining learners. IL in terms of overseeing 'teaching and learning' and 'supervising teachers' was not a function that took up the majority of many school heads' time.

In the Tanzanian context, Sumra and Rajan (2006) found that teachers in secondary schools are seldom in the classroom interacting with students; they are either away or in the staffroom. A study by the World Bank (2010) supported this by showing that Tanzanian teachers spend less time teaching than others worldwide, and there is no evidence to suggest this situation may have significantly improved. When in the classroom most teach using rote techniques requiring students to copy and memorize notes on the board. 
According to Lwaitama and Galabawa (2008) these inefficiencies at school level seem to result from the lack of effective teacher management and supervision. Heads of schools are not facilitated or provided with supervisory skills to ensure that they carry out the role of instructional leaders of fellow teachers in schools.

However, recent researches by Nguni (2005), Ngirwa (2006) and the World Bank (2010) in the area of leadership in the Tanzanian context indicated that very little attention has been devoted to IL, particularly the IL practices engaged in by heads of secondary schools. The World Bank (2010) suggested that a study should be conducted at school level to reveal the HoSs' engagement in IL. This study sought to fill this gap by analysing the IL practices that heads of secondary schools engage in to enhance teachers' classroom instruction and students' learning.

\section{Methodological Approach to the Inquiry}

This study drew on the qualitative inquiry. Relying primarily on a qualitative framework, the study deployed a case study design. The need for a detailed exploration of IL practices engaged in by heads of schools and their in-depth examination within a specific context of secondary schools made this underlying design indispensable. The data collection methods deployed were interviews (face-to-face semi-structured), focused group discussions (FGDs), and observation (participant). These methods were chosen to crossvalidate the data obtained from each method. Both primary and secondary sources of data were employed in data collection. Primary data were collected from key informants through interview, FGDs and observations.

Interviews enabled to probe further to obtain more detailed information from participants. FGDs, on the other hand, opened a room for diverse views. In fact, participants tend to provide checks and balances on each other, which weeds out false or extreme views. Observations were vital for gaining knowledge concerning 'theory-in-use' and the perspectives that the informants were reluctant to directly state in interviews and FGDs. Additionally, observations allowed the researcher to record the natural behaviour of HoSs in their social settings.

The data so collected were analysed thematically. The process of data analysis began at the outset of field work, focusing on transcribed interviews, field notes made during and after interviews, and on 
observations. Three main stages informed data analysis (Huberman \& Miles, 1994). Firstly, data reduction involved transcribing and summarising data from all sources. Data reduction was done on a daily basis. This enabled the researcher to assess the methods and strategies of data generation, and to make adjustments accordingly. Secondly, there was further organization of the reduced data, in terms of generating major themes and sub-themes from oral and written texts.

\section{Sampling Design}

The study involved six secondary school (SSs), a total of 36 informants participated in the study; they included six HoSs, six Senior Academic Masters/Mistresses (SAMs), twelve teachers and twelve students. Both informants and the schools were purposively selected. The study was conducted in Iringa urban. The selected study area was particularly useful because it had mixed characteristics of IL practices; some HoSs engaged in IL while others did not.

\section{Findings and Discussion}

Presentation and discussion of the findings drew upon two research questions: (1) How do informants understand the concept of instructional leadership? (2) What role do heads of school play in managing the instructional programme to enhance teachers' classroom instruction and students' learning?

\section{Informants' Understanding of Instructional Leadership}

Through interview, HoSs were asked to respond to this question: "How familiar are you with the idea/concept of IL? The findings from interview with HoSs indicated that six out of six (100 percent) HoSs were not familiar with the idea of IL. They said it was a new concept to them. One head of school said: "To be honest instructional leadership is a new term to me because I have not heard of it before" (Head of School).

To find out the HoSs' understanding of IL, they were asked: "How would you describe IL? The findings revealed that five out of six (83\%) HoSs were able to articulate many aspects of IL functions. They claimed that IL is a 
kind of leadership that is targeted more on instruction and learning. In the interview one HoS said:

I think instructional leadership is a kind of school leadership that is focused on teaching or instruction. It means prioritizing instructional practices over managerial duties....being in the classroom talking to learners and discussing their work, asking them questions about their studies and how they are helped ... (Head of school).

This quotation shows that, despite the fact that IL was a new idea to heads of schools, majority were able to conceptualize it. However, one HoS had no understanding of IL.

Further, interviews with six SAMs revealed similar views. They said IL ensures that there is effective teaching and learning in school. They added that instructional leaders are facilitators in the sense that they are able to assist others in the teaching and learning process, and are able to demonstrate teaching techniques in the classroom and during general meetings with teachers. One senior academic master said: "[ $[.$.$] well, when I$ thought that ... I thought ... instructional ... would be giving guidance or giving instructions but at the same time being an example of it, you know ... learning by example".

Teachers during interview expressed that IL concerns HoSs taking care of how teachers teach and the way students learn. One teacher said: “... in my view, IL means school leadership that takes much care on teachers' instruction and the way students learn" (School teacher). The findings from FGDs with students revealed that they were not familiar with the concept of IL and were not able to explain what it is. One of the students in FGDs said: "[...] Oh! I have not heard about instructional leadership before ... and I cannot explain it. You need to tell us what it is" (Student).

With regard to the informants understanding of IL, the findings indicated that HoSs, SAMs, teachers and students were not familiar with the idea of IL. The findings are in line with the literature, for example Lwaitama and Galabawa (2008) and the World Bank (2010) established that HoSs have little familiarity with the model of IL and they are not facilitated through having been exposed to it. 


\section{The Role Played by Heads of Schools in Managing the Instructional Programme}

With regard to managing the instructional programme, the study assessed HoSs in four areas as presented hereunder: curriculum coordination, monitoring teachers' classroom teaching, conducting classroom observations, and participation in the review of curriculum materials.

\section{Curriculum Coordination}

This sub-section aimed at finding out whether HoSs made clear who is responsible for coordinating the curriculum in their schools. As such, HoSs were asked the following questions: "Do you make clear who is responsible for coordinating the curriculum at your school?" "If yes, who is responsible for coordinating it?" The findings from interviews with HoSs revealed that six out of six (100 per cent) HoSs made clear who was responsible for coordinating the curriculum at their schools. The study was interested in finding out who was responsible for coordinating the curriculum in the schools. The findings from HoSs showed inconsistency among schools. Three out of six (50 per cent) HoSs said SAMs were responsible, two (33 per cent) said the HoSs were responsible and one said the SAMs, heads of Departments and class teachers all together were responsible for coordinating the curriculum.

Further, the interviews with SAMs and teachers supported the idea that SAMs were responsible for coordinating the curriculum. Four out six (67 per cent) SAMs agreed that they were responsible for coordinating the curriculum in their schools. Two (33 per cent) SAMs said that HoSs were responsible. On the other hand eight out of twelve (67 per cent) teachers maintained that SAMs were responsible for coordinating the curriculum, three (25 per cent) said HOSs were responsible and one pointed out that class teachers were responsible. Yet in focus group discussions, most of the students said SAMs were responsible for curriculum coordination in their schools.

Regarding the role of HoSs in pointing out who is responsible for coordinating the curriculum across the school, the findings tended to suggest that HoSs played their role in making clear who was responsible for curriculum coordination in schools. Most informants indicated that SAMs 
were responsible for coordinating the curriculum in schools. The findings contradict the requirements stipulated in the handbook for heads of secondary schools in Tanzania (1997: 20-21), which clearly directs that heads of departments (HoDs) shall be responsible for coordinating the curriculum in schools. HoDs are vital for ensuring efficiency and effectiveness in the teaching and learning of various school subjects because they are closest to teachers. Furthermore, the findings are also dissimilar to those of Dimmock and Wibly (1995), who found that there is a strong link between HoDs and classroom teachers and high quality teaching and learning.

\section{Monitoring Teachers' Classroom Teaching}

This part focused on finding out whether HoSs monitor teachers' classroom teaching to ensure it covers the syllabi in the given timeframe. HoSs were asked to respond to the following questions: "Do you monitor teachers' classroom teaching to ensure that it covers the syllabi on time?" "If yes, how do you monitor it? The findings from interviews with HoSs showed that six out of six (100 per cent) HoSs monitored classroom teaching. It was important to ascertain how HoSs monitored it. Therefore, HoSs were asked to explain how they monitor classroom teaching. It was noted that HoSs relied on schemes of work, lesson plans, subject logbooks and class journals to monitor classroom teaching. HoSs also held meetings with class teachers and asked students about the extent of syllabi coverage. During the interview one HoS said:

Every Friday teachers bring to my office their schemes of work, lesson plans, subject logbooks and class journal ... to check if subjects, topics and sub-topics are well covered. I sometimes enter classrooms to ask students. I also use meetings with class teachers, this helps me to monitor teachers' classroom teaching (Head of school).

To explore the validity of the HoSs claims, the researcher was interested in establishing whether syllabi for various subjects were covered on time. Through the interviews five out of six ( 83 per cent) SAMs said that the syllabi were not covered on time. The findings from the interviews with teachers supported this view; they said that although HoSs insisted teachers 
to prepare and correctly fill in information in the schemes of work, lesson plans, subject logbooks and class journals, this effort did not result in timely coverage of the syllabi. Teachers further claimed that each academic year comes to an end while many topics remain untaught. They associated the poor academic performance in their schools with the failure to finish the syllabi on time. One teacher said:

[...] We often finish the year with many topics remaining untaught ... and there is no strategy in place to remedy this problem. I think this is one of the reasons why our school continue to perform poorly in national examinations ... (School teacher).

Likewise, in the FGDs, students said the failure of teachers to finish the syllabi contributes to their poor academic performance. One of the students said:

During the form two national examinations I failed to answer many questions because they were about topics that had not been taught. How can you expect one to score division one with such a partial knowledge! ... it is difficulty ... (Student).

When asked why syllabi were not covered timely, seven out of twelve (58 per cent) teachers said that the reason was lack of school goals that focus on ensuring that syllabi were covered before the end of each year. Three (25 per cent) teachers disclosed that HoSs did not emphasize on the need for teachers to finish the syllabi on time. They added that HoSs insisted on the filling of schemes of works, lesson plans and subject logbooks not for purpose of ensuring syllabi are covered timely, but for the sake of formality and that these documents among others, constitute the school inspection documents that are supposed to be there when school inspectors come for inspection. However, two (16 per cent) teachers said that they failed to cover the syllabi on time due to frequent interruptions of instructional time.

These findings tended to suggest that, despite the fact that HoSs constantly reviewed and checked schemes of work, lesson plans, class journals and subjects' logbooks; their efforts didn't result to timely syllabi coverage. This implied that HoSs had not set goals for their schools that would enable teachers to cover the syllabi within a given academic year. 
Contrary to this, Plewis (2011) observed that timely syllabi coverage is an important variable in relation to students' academic progress, in that the more the curricula for the subjects are covered by the teachers, the greater the progress made by students in those subjects. Further, Mwasoo (2011) noted that syllabi coverage is a significant determinant as regards the passing of examinations by students, especially when syllabi are covered in the right way so that students are able to read and understand the content of the subjects. It can therefore be argued that failure to cover the syllabi led to students' ineffective learning.

\section{Conducting Classroom Observations}

The focus of this sub-section was on examining the role of HoSs in conducting classroom observations to enhance teachers' classroom teaching and students' learning. HoSs were asked this question: "Do you conduct informal classroom observations on a regular basis during the teaching and learning process?" Six out of six (100 per cent) HoSs claimed that they regularly conducted classroom observations. The study was interested in finding out how HoSs conducted classroom observations. Thus, HoSs were asked to explain how they conducted classroom observations. The findings from interviews with HoSs revealed that they did not enter classrooms to observe the teaching, but rather they walked around outside the classrooms. During the interview one of the HoSs said:

I walk around outside the classrooms to see what is going on there. I prefer not to enter classrooms when teachers are teaching, but what I do is just pop along the corridors. This helps me to know whether teachers are in classroom teaching (School head).

The study was further interested in finding out why HoSs did not choose to enter classrooms to observe teaching. Four out of six (67 per cent) SAMs in the interview said that HoSs had no interest in classroom observation. Two (33 per cent) SAMs said that HoSs were not in the habit of conducting classroom observation. One SAM said: "The headmaster does not show any interest in how teachers are teaching and how students are learning by visiting and observing what goes on in classrooms with the view to designing appropriate support strategies for teachers". 
Meanwhile, the majority (96 per cent) of teachers said that HoSs do not enter classrooms to observe how teachers are teaching because they believe that direct classroom observation would discourage teachers and that such a practice would mean that HoSs do not trust their teachers. In the interview one teacher said: "The head of school never enters classrooms to see how teachers are teaching because she claims that conducting classroom observation when teachers are teaching would discourage teachers and imply mistrust. So she just observes while walking outside the classrooms".

Furthermore, in the focus group discussions students said that HoSs did not show up in the classroom to observe how teaching and learning was taking place when teachers were in the classroom. One student said: "The head of school never shows up in classes to observe when teachers are teaching, but sometimes he comes in the classroom to ask students how effective is teacher X after that teacher leaves the classroom".

During observation it was noted that most HoSs occasionally walked along the corridors outside the classroom when teaching sessions were in progress. None of them was seen popping in the classes to observing how teaching was carried out by teachers.

Regarding the role of HoSs in conducting classroom observations, the findings indicated that HoSs do not engage in classroom observations for two reasons. Firstly, they lack interest in observing teaching and secondly, they believe that classroom observation would discourage teachers and that such a practice would mean that HoSs do not trust their teachers. The findings contradict the provisions of the heads of school handbook of 1997 supplied by the then Ministry of Education and Culture, which require HoSs to regularly conduct classroom observations in all subjects to ensure that what is taught is in accordance with the syllabi and relevant to the grade level. According to Heck (1992) the amount of time HoSs spend observing classrooms and instruction is one of the most important factors in both teachers' and students' achievement. Through actual classroom observations the HoS is able to discover the strengths and/or weaknesses of each teacher and thereby design appropriate support strategies for him/her.

\section{Participation in the Review of Currículum Materials}

This sub-section explored the role played by HoSs in reviewing curriculum materials to ensure that the curriculum materials used at school are relevant 
and of high quality. HoSs were asked to respond to the following question: "Do you participate in the review of curriculum materials?" The findings from interviews with HoSs revealed that HoSs did not engage in the review of curriculum materials. The researcher was interested in finding out why HoSs did not participate in the review of curriculum materials. The interviews with HoSs indicated that six out of six (100 per cent) HoSs did not consider themselves reviewers of curriculum materials. They claimed that they are only implementers of curriculum materials, reviewing curriculum materials was the responsibility of the Education Materials Approval Committee (EMAC). During the interview one HoS said:

We are mere implementers of curriculum materials; we are not empowered to review them but rather the EMAC is the one entitled to do this. Sometimes we encounter challenges and weaknesses in some aspects of curriculum materials usage, but we don't have a voice on this (Head of school).

Further, four out of six (67 per cent) SAM in the interview said that HoSs did not critically examine the curriculum materials used in schools. One SAM said:

This is a problem with the head of school ...he does not critically examine the syllabi, textbooks, teachers' guides, practical manuals or other reference materials to see if they meet the standards especially nowadays when anyone can write a book and sell it in schools or bookshops (School senior academic mistress).

The remaining two (33 per cent) SAMs said they did not know whether their HoS reviewed curriculum materials. In addition, teachers during the interview pointed out that the Ministry of Education and Vocational Training has not recognized the significance of involving HoSs in the review of educational materials. One teacher said:

The Ministry of Education and Vocational Training has not empowered heads of schools to undertake this important task. It should empower them to review the teaching and learning materials and finally report on 
the quality, adequacy, and accuracy of the mushrooming number of textbooks used in schools (School teacher).

With regard to the role played by HoSs in reviewing curriculum materials, the findings tended to suggest that HoSs do not engage in the review of curriculum materials. Contrary to this, however, Hallinger (2008) and Gillet (2010) noted that HoSs as instructional leaders have the responsibility of reviewing curriculum materials at the school level to ensure that the teaching and learning materials used by teachers and students are of high quality. Furthermore, Hakielimu (2011) found that most of the text books used in Tanzanian secondary schools contain a lot of mistakes, let alone grammatical, semantic or other problems, although they have been approved by the EMAC. Basing on these findings it can be argued that to attain quality of curriculum materials in our schools, the review of curriculum materials should not be left to EMAC alone, but HoSs as key supervisors of curriculum implementation at the school level should be capacitated and actively involved in the review process.

\section{Conclusions and Recommendations}

In light of the findings of the research the following conclusions can be drawn:

Firstly, heads of community schools were not familiar with the model of instructional leadership and that their general understanding of IL as revealed in the study did not help them to carry out the specific functions of IL.

Secondly, heads of schools were not effective in managing the instructional programme in their schools. Their ineffective engagement in IL was due to their capacity constraints; they had limited knowledge of IL.

In this regards, the researcher recommends the following:

Firstly, capacity building programmes for HoSs should focus on acquainting them with the model of IL and capacitate them to lead the changes in instruction that may result in higher levels of learning for all students. 
Secondly, HoDs should be actively involved in curriculum coordination in schools and their appointment should be based on merit, i.e., expertise, experience and hardworking.

Thirdly, heads of schools should establish goals and strategies focused on enabling teachers to cover the subjects' syllabi on time before students sit for their final annual examinations.

Fourthly, the Ministry of Education and Vocational Training should capacitate and actively involve HoSs in the review of curriculum materials. This crucial IL task should not be left to EMAC alone.

Lastly but not least, HoSs should actively and regularly engage in actual classroom observations when teachers are teaching in the classrooms. This may help HoSs to discover the strengths and/or weaknesses of teachers and thereof design appropriate support programmes for them.

\section{References}

Day, C., Harris, A., Hadfield, M., Tolley, H., \& Beresford, J., (2000). Leading schools in times of change. Buckingham: Open University Press.

Dimmock, C., \& Wildy, H. (1995). Conceptualizing curriculum management in an effective secondary school: A Western Australian case study. The Curriculum Journal, (22)6, 297-323. doi: 10.1080/0958517950060303

Elmore, R. (2000). Building a new structure for school leadership. Washington DC: The Albert Shanker Institute.

Galabawa, J. C. J., \& Nikundiwe, A. M. (2000). “Why Ugandan secondary schools do well” in Galabawa, J. C. J. et al., Quality of education in Tanzania: Issues and experiences. Dar es Salaam: University of Dar es Salaam.

Gillet, J. (2010). The making of the preferred principal. South African Educational Leader, (7)2, 1-11.

Heck, R. H. (1992). Principals' instructional leadership and school performance: Implications for policy development. Educational Evaluation and Policy Analysis, (14)1, 21-34. doi: 10.3102/01623737014001021

Hakielimu, (2011). The relationship between curriculum and education quality. Dar es Salaam: Hakielimu. 
Hallinger, P. (2005). "Instructional leadership: How has the model evolved and what have we learned?" Paper presented at the annual meeting of the American Educational Research Association, April 2005. Montreal, Canada.

Hallinger, P. (2008). "Methodologies for studying school leadership: A review of 25 years of research using the principal instructional management rating scale." Paper presented at the annual meeting of the American Educational Research Association, June 2008. New York.

Hallinger, P., \& Walker, A. (2014). Exploring whole school vs. subject department improvement in Hong Kong secondary schools. School improvement and school effectiveness. Retrieved from http://www.philliphallinger.com. on $1^{\text {st }}$ April 2015.

Hoadly, U., Christie, P., Jacklin, H., \& Ward, C. (2007). Managing to learninstructional leadership in South African secondary schools. Cape Town: University of Cape Town.

Hoy, W., \& Miskel, C. (2008). Educational administration: Theory, research and practice. New York: McGraw Hill.

Huberman, A. M., \& Miles, M. B. (1994). Data management and analysis methods. In Denzin, N. K., \& Lincoln, Y.S. Handbook of Qualitative Research (pp. 428- 444). London: Sage Publications.

Jita, L. C. (2010). Instructional leadership for the improvement of science and mathematics in South Africa. Procodia-Social and Behavioral Sciences,(9)2, 851-854. doi: 10.1016/j.sbspro.2010.12.247

King, D. (2002). The changing shape of leadership. Educational Leadership, (59)8, 61-63.

Lwaitama, A. L., \& Galabawa, J. C. J. (2008). "Community secondary schools: How long is their journey to quality education." Paper presented as a contribution to the on-going national education debate, $21^{\text {st }}$ October 2008. Dar es Salaam: Tanzania Education Network (TEN).

McEwan, E. K. (2009). Ten traits of highly effective schools: Raising the achievement bar for all students. Thousand Oaks: Corwin Press.

Ministry of Education and Vocational Training (MoEVT), (2011). Secondary education development programme II, final draft July 2010-June 2015. Dar es Salaam: MoEVT. 
Mwasoo, D. (2011). Does syllabi coverage enable students to pass exams? Nairobi:Nairobi University Press.

Ngirwa, C. C. (2006). The effects of leadership styles in promoting academic performance in primary education. M.A. (Ed) Dissertation, Dar es Salaam: University of Dar es Salaam.

Nguni, S. (2005). Transformational leadership in Tanzania education: A study of the effects of transformational leadership on teachers' job satisfaction, commitment and organizational citizenship behavior in Tanzania primary and secondary schools. Doctoral thesis, Rod bound University.

Plewis, I. (2011). Curriculum coverage and classroom grouping as explanation of teacher differences in students' mathematics progress. Educational Research and Evaluation, (4)2, 97- 107.

Pustejovsky, J., Spillane, J.P., Heaton, R.M., \& Lewis, W. J. (2009). Understanding teacher leadership in middle school mathematics: A collaborative research effort. Journal of Mathematics and Science: Collaborative Explorations, (11)2, 19-40.

Spillane, J., Halverson, R., \& Diamond, J. (2000). Towards a theory of leadership practice: A distributed perspective. Evanston: Institute for Policy Research.

Spillane, J. P., Camburn, E. M., \& Pareja, A. S. (2007). Taking a distributed perspective to the school principal's workday. Leadership and Policy in Schools, (6)1, 103-125. doi: 10.1080/15700760601091200

Spillane, J. P., \& Zuberi, A. (2009). Designing and piloting a leadership daily practicelog: Using logs to study the practice of leadership. Educational Administration Quarterly, (45)3, 375-423. doi: 10.1177/0013161X08329290

Sumra, S. \& Rajani, R. (2006). Secondary education in Tanzania: Key policy challenges. Dar es Salaam: Hakielimu.

World Bank, (2010). Recruiting, retaining, and retraining secondary school teachers and principals in Sub-Saharan Africa. Washington DC: The World Bank. 
Aaron Mkanga Manaseh is Assistant Lecturer at Mkwawa University College of Education in the United Republic of Tanzania.

Contact adress: manasehaaron@yahoo.com 